\title{
Persepsi Mahasiswa Mengenai Beban Tugas Membaca Terhadap Minat Baca Mahasiswa
}

\author{
Hengki Wijaya, ${ }^{1}$ Mega Lisda, ${ }^{2}$ Ivan Th. J. Weismann, ${ }^{3}$ Tri Supartini, ${ }^{4}$ Ezra Tari ${ }^{5}$ \\ 1,2,3,4 Sekolah Tinggi Filsafat Jaffray Makassar \\ ${ }^{5}$ Institut Agama Kristen Negeri Kupang \\ 1hengkilily1988@gmail.com
}

\begin{abstract}
This paper is a survey study of student perceptions regarding the burden of reading assignments on students' reading interest. In this digital era, students' reading interest in textbooks has decreased. The level of visits to the library has reduced. The rate of accessing digital content is higher than reading books. The purpose of this study was to examine the reading interest of students who were given reading assignments. The research method used by the author is quantitative. This method statistically analyzes students' reading interest. Based on the research, First, students read books because they are related to grades. Second, the reading task makes the level of interest in reading increase. Third, students can respond well to reading materials. Fourth, the workload can increase STF Jaffray Makassar library visits.
\end{abstract}

Keywords: Lecturers, Reading, Students, task load, interest in reading

\begin{abstract}
Abstrak:
Tulisan ini merupakan kajian survey persepsi mahasiswa mengenai beban tugas baca terhadap minat baca mahasiswa. Di era digital ini, minat baca mahasiswa terhadap buku teks mengalami penurunan. Tingkat kunjungan ke perpustakaan mengalami penurunan. Tingkat mengakses konten digital lebih tinggi dibanding buku bacaan. Tujuan penelitian ini adalah mengkaji minat baca mahasiswa yang diberikan tugas baca. Metode penelitian yang dipakai penulis adalah kuantitatif. Metode ini menganalisis secara statistik minat baca mahasiswa. Berdasarkan penelitian, Pertama, mahasiswa membaca buku karena berkaitan dengan nilai. Kedua, tugas membaca membuat tingkat minat baca meningkat. Ketiga, mahasiswa dapat menanggapi dengan baik bahan bacaan. Keempat, beban tugas dapat meningkatkan kunjungan perpustakaan STF Jaffray Makassar.
\end{abstract}

Kata Kunci: Bacaan, Dosen, Mahasiswa, beban tugas, minat baca

\begin{tabular}{llll}
\hline Article History : & Received: 23-02-2021 & Revised: 04-06-2021 & Accepted: 07-06-2021
\end{tabular}

\section{Pendahuluan}

Pendidikan merupakan proses belajar mengajar dalam diri seseorang agar dapat berpikir secara cerdik dan lebih bijaksana. Oleh sebab itu pendidikan merupakan sarana terpenting dalam mewujudkan cita-cita bangsa. ${ }^{1}$ Pada dasarnya seseorang dikatakan sukses dalam pendidikan ketika telah lancar membaca, karena dengan membaca

1 Magdalia Alfian, "Pendidikan Sejarah Dan Permasalahn Yang Dihadapi," Khazanah Pendidikan 3, no. 2 (February 1, 2011): 1-8. 
seseorang dapat meilihat dunia dengan pengetahuan luas yang dimilikinya. Sehingga membaca adalah kebiasaan baik untuk meningkatkan pengetahuan seseorang. Jika biasa membaca akan meluaskan wawasan, maka dengan membaca juga akan membuat seseorang akan mengetahui banyak hal. ${ }^{2}$

Secara umum tuntutan di era globalisasi bukan menjadi sebuah ancaman bagi manusia, karena pada dasarnya manusia selalu ingin mencari tahu sesuatu yang baru. "Membaca adalah kunci ilmu, membaca dijadikan sebagai jendela dunia." 3 Orang harus membaca untuk dapat melihat dunia. Membaca memiliki peran penting karena membuat seseorang mendapatkan informasi yang baru maupun pengetahuan yang baru. Membaca memiliki banyak manfaat dalam kehidupan. ${ }^{4}$ Kemampuan membaca dan minat yang tinggi adalah modal dasar untuk keberhasilan anak dalam berbagai mata pelajaran. ${ }^{5}$ Keterampilan membaca juga merupakan salah satu modal utama bagi anak. Kemampuan membaca anak dapat mempelajari sesuatu yang diinginkan. ${ }^{6}$ Karena kemampuan membaca merupakan hal yang sangat dibutuhkan pada saat berbahasa. ${ }^{7} \mathrm{Di}$ kalangan mahasiswa, membaca merupakan hal yang sangat penting membaca adalah proses aktif yang bertujuan dengan memerlukan strategi. ${ }^{8}$ Kenyataan yang terjadi di kampus adalah rendahnya minat membaca seseorang menyebabkan mutu dan kualitas pendidikan cenderung mundur. ${ }^{9}$

Kegiatan membaca di Indonesia masih rendah dan belum dijadikan sebuah kebiasaan. Rendahnya minat membaca seseorang memiliki sejumlah dampak negatif. ${ }^{10}$ Membaca mungkin kegiatan yang mudah dilakukan, namun susah untuk dijadikan kebiasaan. Bosan, jenuh, cepat menghampiri ketika mulai melakukan kegiatan membaca, sehingga generasi muda merasa bahwa membaca merupakan kegiatan yang

\footnotetext{
${ }^{2}$ Srindahningsih, Jurus Epic Membaca: Cara Menciptakan Hobi Membaca (Sidoarjo: Embrio Plugbise, 2017)

${ }^{3}$ Ibunda Aini, Membaca \& Menulis Seasyik Bermain (Bandung: Mizan Media Utama, 2006).

${ }^{4}$ Siti Purnama Sari, Andika Triansyah, and Eka Supriatna, "Minta Membaca Mahasiswa Pendidikan Jasmani Di Perpustakaan Jurusan Ilmu Keolahragaan," Jurnal Pendidikan dan Pembelajaran Khatulistiwa 8, no. 3 (March 21, 2019): 1-11.

${ }^{5}$ Rivda Yetti, "Pengaruh Keterlibatan Orang Tua Terhadpa Minat Membaca Anak Ditinjau Dari Pendekatan Stres Lingkungan," PEDAGOGI / Jurnal Ilmiah Ilmu Pendidikan IX, no. 1 (August 14, 2009): 17 28.

${ }^{6}$ Sri Wahyuni, "Menubuhkembangkan Minat Baca Menuju Masyarakat Literat," Diksi 16, no. 2 (November 4, 2015): 1-11.

${ }^{7}$ Sari, Triansyah, and Supriatna, "Minta Membaca Mahasiswa Pendidikan Jasmani Di Perpustakaan Jurusan Ilmu Keolahragaan."

${ }^{8}$ Hidayat Wahyu Iwan, Keterampilan Belajar (Study Skills) Untuk Mahasiswa (Jakarta: Kencana, 2018).

${ }^{9}$ Meliyawati, Pemahaman Dasar Membaca (Yogyakarta: Deepublish, 2016).

${ }^{10}$ Uci Sugiarti, "Pentingnya Pembinaan Kegiatan Membaca Sebagai Implikasi Pembelajaran Bahasa Indonesia," Basastra 1, no. 1 (June 27, 2012): 1-11.
} 
membosankan. ${ }^{11}$ Penelitian Hasibuan juga mengungkapkan bahwa ada perbedaan minat pilihan bacaan yang dipilih oleh mahasiswa (laki-laki) dan mahaisiswi (perempuan). Persamaannya adalah lebih memilih bacaan e-book, dan sumber elektronik. ${ }^{12}$ Penelitian Sunaiyah menjelaskan "tugas menulis dapat mengasah kemampuan pelajar dalam menjelaskan konsep membaca, melakukan proses pemahaman bacaan, mengetahui tujuan membaca, mampu menyimpulkan bacaan karya ilmiah dan mampu mengakses internet untuk memenuhi tugas menulis." 13 Minat dan kebiasaan membaca memengaruhi prestasi belajar dalam materi pelajaran geografi. ${ }^{14}$ Penelitian Romafi dan Musfiroh menunjukkan bahwa ada korelasi positif antara minat membca dan tugas membaca terhadap pemahaman membaca. ${ }^{15}$ Penelitian Hidayah, Suwandi dan Hastuti bahwa penerapan Preview, Question, Read, Summarize, Test (PQRST) dapat meningkatkan minat baca dan membaca pemahaman siswa. ${ }^{16}$ Dengan demikian ada korelasi beban tugas, minat baca, kemampuan membaca, dan hasil belajar.

Ketika mahasiswa semester akhir berniat membaca sebuah jurnal ataupun tulisan ilmiah mereka hanya langsung melihat bagian akhir dari kesimpulan jurnal atau tulisan ilmiah tersebut tanpa membaca bagaimana prosesnya. ${ }^{17}$ Demikian juga yang dialami oleh mahasiswa di Sekolah Tinggi Filsafat Jaffray Makassar (STF Jaffray Makassar), mahasiswa sering dikaitkan dengan pembacaan secara akademik membaca untuk keperluan akademik identik dengan membaca kritis yaitu proses membaca untuk mengolah bahan bacaan secara kritis dan menemukan keseluruhan makna bahan bacaan baik tersurat maupun tersirat. 18

Penulis juga melakukan wawancara dengan beberapa dosen tentang pentingnya membaca. Dengan pertanyaan: Sebagai dosen yang memberikan tugas-tugas kepada

\footnotetext{
11 I Made Ngurah Surangga, "Mendidik Lewat Literasi Untuk Pendidikan Berkualitas," Jurnal Penjaminan Mutu 3, no. 2 (August 31, 2017): 154-163.

12 Sri Wahyuni Hasibuan, "Kebiasaan Membaca Dan Pilihan Bacaan Pada Mahasiswa Pria Dan Wanita Di Universita Pembangunan Panca Budi," JUMANT 10, no. 2 (December 11, 2018): 75-84.

${ }^{13}$ Salma Sunaiyah, "Memacu Minat Membaca Bebas (Perpstakaan) Melalui Tugas Menulis," UNIVERSUM: Jurnal KeIslaman dan Kebudayaan 9, no. 1 (January 1, 2015): 117-129.

${ }^{14}$ Onik Farida Ni'matullah, "Pengaruh Minat Dan Kebiasaan Membaca Siswa Terhadap Hasil Belajar Geografi SMA," JPIG (Jurnal Pendidikan dan Ilmu Geografi) 3, no. 1 (2018): 197-205.

${ }^{15}$ Romafi Romafi and Tadkiroatun Musfiroh, "Hubungan Minat Membaca, Fasilitas Orang Tua, Dan Pemberian Tugas Membaca Dengan Kemampuan Membaca Pemahaman Siswa," LingTera 2, no. 2 (October 3, 2015): 185-199.

${ }^{16}$ Nurul Hidayah, Sarwiji Suwandi, and Sri Hastuti, "Penerapan Metode PQRST Untuk Meningkatkan Minat Dan Kemampuan Membaca Pemahaman Siswa," BASASTRA 2, no. 3 (August 1, 2014), accessed June 4, 2021, https://jurnal.fkip.uns.ac.id/index.php/bhs_indonesia/article/view/7792.

17 Iwan, Keterampilan Belajar (Study Skills) Untuk Mahasiswa.

${ }^{18}$ Yunus Laukapitang, Wawancara Oleh Penulis, 25 Maret. (Makassar, 2019).
} 
mahasiswa, dan salah satu tugas tersebut adalah laporan bacaan. Jawaban dari beberapa dosen menyatakan setuju dengan membaca maka mahasiswa memiliki pemahaman sehingga dengan adanya laporan bacaan, mahasiswa di kelas ada umpan balik dalam pelajaran dan ini dapat meningkatkan semangat mereka dalam membaca. Mahasiswa banyak maka di perpustakaan juga penuh, kalau tugas kurang mahasiswa juga kurang minat ke perpustakaan, apalagi membaca kami sebagai petugas jarang melihat mahasiswa yang benar-benar duduk tenang membaca, mahasiswa ke perpustakaan tergantung keperluan masing-masing. ${ }^{19}$ Dengan demikian rumusan masalah penelitian ini adalah bagaimana persepsi mahasiswa mengenai beban tugas membaca memengaruhi minat baca mahasiswa STF Jaffray Makassar?

\section{Metode Penelitian}

\section{Desain Penelitian}

Penulis menggunakan jenis penelitian kuantitatif. Penelitian kuantitatif adalah pemahaman peneliti berdasarkan pengalaman kemudian dikembangkan menjadi permasalahan beserta pemecahan yang diajaukan untuk memperoleh pembenaran dalam bentuk dukungan data empiris di lapangan. ${ }^{20}$ Penelitian kuantitatif mengumpulkan data dengan cara penyebaran angket dan wawancara. ${ }^{21}$ Angket dan wawancara digunakan sebagai pengumpulan informasi terkait sejauh mana pengaruh beban tugas terhadap peningkatan minat baca, guna mendapatkan hasil yang diharapkan dari penelitian.

\section{Populasi Dan Sampel}

Populasi adalah keseluruhan objek dengan ciri yang sama, populasi terdiri dari orang, benda, kejadian, waktu, dan tempat dengan sifat atau ciri yang sama. ${ }^{22}$ Berdasarkan pengertian populasi maka dapat disimpulkan bahwa populasi merupakan segala sumber yang berasal dari makhluk hidup dan benda-benda yang ada di lokasi sebagai sarana penelitian. Adapun populasi dalam penelitian ini adalah mahasiswa STF Jaffray. Angkatan 2015, angkatan 2016, angkatan 2017 dan angkatan 2018 dengan jumlah keseluruhan 439 orang.

Sampel merupakan suatu prosedur yang hanya sebagian dari populasi yang diambil serta digunakan untuk menentukan sifat dan ciri yang dikehendaki dari

\footnotetext{
${ }^{19}$ Hendrik Sello, Wawancara Oleh Penulis, 6 Februari (Makassar, 2019).

${ }^{20}$ Ahmad Tanzeh, Metodologi Penelitian Praktis (Yogyakarta: Teras, 2011), 63-64.

21 Emzi, Metodologi Penelitian Kuantitatif Dan Kualitatif (Bandung: Grafindo, 2010), 28.

22 Nana Syaodih S, Metode Penelitian Penididikan (Bandung: Remaja Rosdakarya, 2009), 58.
} 
populasi."23 Dalam penelitian kuantitatif, sampel adalah bagian dari jumlah dan karakteristik yang dimiliki oleh populasi. Untuk itu sampel yang diambil dari populasi harus benar-benar mewakili semuanya." 24 Sampel yang penulis gunakan adalah mahasiswa berjumlah 105 orang. Dan teknik sampel menggunakan rumus sebagai berikut:

Rumus Isaac \& Michael (1981-92):25

$\mathrm{S}=\frac{\mathrm{X}^{2} \cdot \mathrm{N} \cdot \mathrm{P}(1-\mathrm{P})}{\mathrm{d}^{2}(\mathrm{~N}-1)+\mathrm{X}^{2} \cdot \mathrm{P}(1-\mathrm{P})}$

Keterangan:

S= Jumlah sampel

$\mathrm{N}=$ Jumlah Populasi

$\mathrm{P}=$ Proporsi dalam populasi $(\mathrm{P}=0,50)$

$\mathrm{d}=$ Ketelitian/ derajat ketetapan $(0,50)$

$X^{2}=$ Nilai table chi kuadrat untuk ocx tertentu $\left(X^{2}=3,841\right.$ taraf Signifikasi 95\%).

\section{Teknik Pengumpulan Data}

Dalam penelitian yang penulis lakukan di kampus STF Jafrray Makassar, penulis melakukan penelitian terhadap mahasiswa. Dan teknik pengumpulan data yang penulis gunakan adalah sebagai berikut:

\section{Observasi}

Observasi adalah pengamatan dan pencatatan yang sistematis terhadap gejala-gejala yang diteliti. ${ }^{26}$ Observasi dilakukan untuk memperoleh data keadaan gambaran lokasi penelitian, keadaan siswa dan dosen dalam lokasi penelitian guna untuk memperlengkapi penelitian ini. Untuk mendapatkan data yang lebih akurat penulis menggunakan hasil dari angket dan wawancara. Penulis dalam hal ini mengarahkan penelitian yang berlokasi di STF Jaffray Makassar dan populasi yang dimaksud oleh penulis di sini adalah angkatan 2015 sebanyak 97 orang, angkatan 2016 sebanyak 104 orang, angkatan 2017 sebanyak 104 orang dan angkatan 2018 sebanyak 134 orang.

23 Moh. Nazir, Metode Penelitian (Jakarta: Ghalia Indonesia, 1988), 325.

24 Ibid., 168.

${ }_{25}$ Mikha Agus Widiyanto, Statistika Untuk Penelitian Bidang Teologi, Pendidikan Agama Kristen, \& Pelayanan Gereja (Kalam Hidup: Bandung, 2014), 87. 54.

${ }^{26}$ Husaini Usman dan Purnomo Setiady, Metodologi Penelitian Sosial (Jakarta: Bumi Aksara, 1996), 


\section{Angket}

Angket adalah daftar pertanyaan atau pernyataan yang diberikan kepada responden baik secara langsung maupun tidak langsung. ${ }^{27}$ Angket berupa instrumen dari penelitian berupa daftar pertanyaan atau pernyataan secara tertulis yang harus dijawab atau diisi oleh respondensesuai dengan bentuk pengisiannya. ${ }^{28}$ Angket yang disebarkan bersifat tertutup karena jawaban atau pernyataan yang telah disediakan pada kolom jawaban. Responden perlu memilih salah satu jawaban yang paling sesuai dengan keadaan responden. Angket menggunakan skala Likert dengan jawaban dari skor tertinggi 4 sampai skor terendah 1, dengan pilihan jawaban "Selalu", "Sering", "Jarang", dan "Tidak Pernah".

\section{Wawancara}

Wawancara adalah salah satu metode pengumpulan data dengan mendapatkan informasi dengan cara bertanya langsung kepada responden. ${ }^{29}$ Menurut Hadi dan Haryono wawancara merupakan pertemuan antara dua orang untuk bertukar informasi atau ide melalui tanya jawab. ${ }^{30}$ Oleh sebab itu, wawancara adalah pertemuan dua orang untuk bertukar informasi dengan cara tanya jawab. Wawancara dilakukan bertujuan menguatkan dan mendapatkan hasil penelitian yang valid dalam penulisan.

\section{Teknik Analisa Data}

Melalui data yang telah dikumpulkan melalui penelitian angket dan wawancara, maka akan dianalisis dengan menggunakan teknik kuantitatif. Dan rumus yang digunakan dalam menganalisis data adalah:

$\%=\frac{n}{N} \times 100$

Keterangan: 31

$\%=$ Persentase

$\mathrm{n}=$ Jumlah jawaban responden

$\mathrm{N}=$ Jumlah responden

Selanjutnya mengukur Rating skala indikator minat baca dengan mengunakan rumus: ${ }^{32}$

${ }^{27}$ Sugiyono, Metode Penelitian Kuantitatif Dan R\&D (Bandung: Alfabeta, 2014), 215.

${ }^{28}$ Wina Sanjaya, Penelitian Pendidikan (Jenis, Metode dan Prosedur) (Jakarta: Predamedia Group, 2013), 255.

${ }^{29}$ Muh Fitrah \& Luthfiyah, Metodologi Penelitian: Penelitian Kualitatif, Tindakan Kelas \& Studi Kasus (Jawa Barat: Jejak Publisher, 2018), 65.

${ }^{30}$ Muh Fitrah \& Luthfiyah, Metodologi penelitian: penelitian kualitatif, tindakan kelas \& studi kasus (CV Jejak (Jejak Publisher), 2018).

31 Muhammad Ali, Penelitian Kependidikan (Bandung: Angkasa, 1981), 184. 
$\%=\frac{M}{n \times m \times p} \times 100$

Keterangan:

$\%=$ Persentase

$\mathrm{M}=$ Jumlah jawaban responden semua pertanyaan dalam satu indikator

$\mathrm{n}=$ Jumlah responden

$\mathrm{m}=$ jumlah pertanyaan

$\mathrm{p}=$ nilai tertinggi penilaian; $\mathrm{p}=4$

\section{Hasil dan Pembahasan}

Dalam tulisan ini dijelaskan teori tentang minat belajar dan indikator minat membaca. Selanjutnya hasil analisis data persentase kuesioner dan rating skala per indikator. Kemudian Penulis membahas hasil penelitian dengan mendeskripsikan hasil dan membahas sesuai dengan teori.

\section{Pengertian Minat Baca}

Menurut Bond minat baca adalah seberapa sering seseorang melakukan aktivitas membaca. Menurut Tinker mengatakan bahwa minat baca adalah kecenderungan yang diperoleh secara bertahap untuk merespons secara selektif, positif, disertai rasa puas terhadap hal-hal khusus yang dibaca. ${ }^{33}$

Minat baca merupakan aktivitas yang dilakukan dengan ketekunan serta penunjang paling penting untuk mendorong rasa ingin tahu terhadap sesuatu bacaan untuk mengetahui informasi yang awalnya tidak diketahui menjadi tahu. ${ }^{34}$ Minat baca berbicara tentang seseorang tekun dengan rasa ingin tahunya, ketika anak mempunyai rasa ingin tahu yang tinggi maka hari-harinya seseorang tidak akan berhenti mencoba dan mau melihat suatu yang berbeda, itulah pentingnya minat baca untuk membantu anak untuk mencapai keinginannya. Menurut pendapat Ginting tentang minat baca adalah bentuk-bentuk perilaku yang terarah guna melakukan kegiatan membaca sebagai tingkat kesenangan yang kuat dalam melakukan kegiatan membaca karena menyenangkan dan memberikan nilai. ${ }^{35}$ Minat baca ditunjukkan dengan keinginan yang

\footnotetext{
32 Sugiyono, Metode Penelitian Pendidikan Pendekatan Kuantitatif, Kualitatif, Dan R\&D (Bandung: Alfabeta, 2014); Hengki Wijaya, Metodologi Penelitian Pendidikan Teologi (Makassar: Sekolah Tinggi Theologia Jaffray Makassar, 2016).

${ }^{33}$ Irwan P. Ratu Bangsawan, Minat Baca Siswa (Banyuasin: Dinas Pendidikan, Pemuda, Olahraga dan Pariwisata, 2018), 36.

${ }^{34}$ Meliawaty, Pemahaman Dasar Membaca (Yogyakarta: Budi Utama, 2016),32.

35 Ibid., 31.
} 
kuat untuk melakukan kegiatan membaca. ${ }^{36}$ Minat baca menurut Sutarno adalah suatu dorongan yang datang dari dalam hati sesorang untuk membaca. ${ }^{37}$ Seseorang harus memiliki keinginan yang kuat untuk mencapai sesuatu demi keberhasilan yang baik, sehingga dengan adanya dorongan yang ada dalam pribadi seorang, akan membuat pribadi anak itu semakin senang dalam membaca. Sedangkan menurut Wahadaniah menjelaskan bahwa minat baca adalah keinginan yang kuat disertai usaha-usaha seseorang untuk membaca. Dan menurut Tampubolon menjelaskan bahwa minat adalah perpaduan antara keinginan dan kemauan yang dapat berkembang jika ada motivasi. ${ }^{38}$ Minat baca dapat membuat pembaca memiliki arah dalam kegiatan membaca, sehingga hal itu akan menjadi suatu kegiatan yang menyenangkan dan akan terus dilakukan. Minat baca harus dimiliki oleh pembaca, melalui minat baca membuat pembaca memiliki rasa senang karena minat berbicara tentang kesenangan. Minat baca merupakan kecendrungan jiwa yang mendorong seseorang untuk berbuat sesuatu untuk membaca.

\section{Indikator Minat Baca}

Dalam memenuhi kebutuhan anak dalam pendidikan, dibutuhkan banyak perlengkapanperlengkapan yang menunjung, demi terpenuhinya alat belajar anak. Bahan bacaan merupakan salah satu indikator yang dapat dijadikan alat bantu perkembangan setiap individu. Banyak daerah yang memacu pendidikan untuk meningkatkan minat membaca, sebab menurut penelitian dan pengalaman dengan membaca, individu dapat meningkatkan pola pikir dan kemampuan nalarnya dengan bahan bacaan. ${ }^{39}$ Jika seseorang lebih sering memboroskan waktu luang, maka seseorang harus mencari cara dalam memanfaatkan waktu. Perlu adanya inovasi untuk menemukan hal-hal yang baru dalam menambah suatu minat. ${ }^{40}$ Dapat menggunakan waktu dengan baik merupakan salah satu cara seseorang mengukur minatnya dalam membaca, karena dapat dilihat cara menciptakan suatu keterampilan ketika mempunyai pengetahuan yang banyak dan mencapai suatu keterampilan yang baik harus ada proses yang dimiliki oleh anak.

Minat tidak dimiliki oleh orang begitu saja, minat tidak begitu saja ada dalam diri seseorang melainkan timbur karena adanya pengalaman dan usaha yang dimiliki.

\footnotetext{
36 Darmono, Perpustakaan Sekolah (Jakarta: Grasindo, 2007), 214.

${ }^{37}$ Perpustakaan Proklamator Bung Karno, Buletin Perpustakaan Bung Karno. Th. IX / Vol. I / 2017: Media Informasi Perpustakaan Bung Karno (Perpustakaan Proklamator Bung Karno), 28.

38 Irwan P. Ratu Bangsawan, Minat Baca Siswa (Bayuasin: Dinas Pendidikan Pemuda, Olahaga dan Pariwisata, 2018), 34,: D. P. Tampubolon, Kemampuan Membaca, Teknik Membaca Efektif dan Efisien (Bandung: Angkasa, 1989).

39 I Kerut Gede Yudandara, Mengubah Ketidakpastian Menjadi Kekuatan (Jakarta: Elex Media Komputindo, 2006), 47.

40 Peng Kheng Sun, To Be an Innovator (Jakarta: Gramedia Pustaka Utama, 2013), 146.
} 
Menurut Firdaus indikator minat adalah kualitas membaca anak sangat berpengaruh oleh keberhasilannya dalam belajar dan dalam kehidupannya. Inidkator minat baca dibagi menjadi empat aspek, yakni (1) kesukaan yang indikatornya gairah dan inisiatif, (2) ketertarikan indikatornya responsive dan kesegeraan, (3) perhatian yang indikatornya konsentrasi dan ketelitiaan, (4) keterlibatan intikatornya kemauan dan keuletan. ${ }^{41}$ Aspek minat baca anak menurut Safari sebagai berikut: ${ }^{42}$

a. Perasaan senang

Seorang siswa yang memiliki perasaan senang atau suka terhadap suatu mata pelajaran, maka siswa tersebut akan mempelajarinya terus-menerus, tidak ada perasaan terpaksa pada saat mempelajari bidang tersebut.

b. Ketertarikan siswa

Berhubungan dengan daya gerak yang mendorong untuk cenderung merasa tertarik pada orang, benda, kegiatan atau bisa berupa pengalaman.

c. Perhatian siswa

Perhatian merupakan kosentrasi atau aktivitas jiwa terhadap pengamatan dan pengertian, siswa yang memiliki minat objek tertentu, dengan sendirinya akan memperhatikan objek tersebut.

d. Keterlibatan siswa

Keterlibatan seseorang akan suatu objek akan mengakibatkan orang tersebut senang dan tertarik untuk melakukan atau mengerjakan kegiatan tersebut.

Memiliki keinginan atau kemauan yang kuat akan mempengaruhi keberhasilan seorang anak, perlu adanya aspek-aspek yang tertanam dalam diri seorang anak agar adanya minat baca antara lain, pertama ada perasaan senang. Pada saat seseorang merasa senang dengan mata pelajaran tertentu maka siswa tersebut akan membaca buku-buku tentang pelajaran tersebut. Kedua, adanya ketertarikan pada siswa. Saat siswa memiliki ketertarikan pada suatu hal seperti orang atau teman dekat atau benda yang ingin dimiliki, siswa tersebut akan mempunyai cara agar mendapatkannya, sehingga hal itu dapat menjadikan siswa tersebut termotivasi dalam pendidikan, ketiga adanya perhatian dari siswa. Adanya perhatian pada suatu objek akan membuat siswa menjadi konsentrasi dalam mengamati atau memahami, dan keempat, adanya

41 Ony Dina Maharani, “Minat Baca Anak-Anak Di Kampoeng Baca Kabupaten Jember,” Jurnal Review Pendidikan Dasar: Jurnal Kajian Pendidikan dan Hasil Penelitian 3, no. 1 (January 15, 2017): 320 328, accessed April 30, 2019, https://journal.unesa.ac.id/index.php/PD/article/view/1646.

42 Ibid.3. 
keterlibatan siswa menyebabkan siswa saling berinteraksi karena senang dan merasa tertarik.

Berikut ini adalah hasil mengenai indeks membaca masyarakat Jawa Barat yang diukur berdasarkan tiga indikator yaitu ketersediaan fasilitas membaca, pemanfaatan sumber bacaan, dan kebiasaan membaca. ${ }^{43}$ Fasilitas pada saat membaca dapat membuat menunjang minat anak dalam membaca, seperti buku-buku yang lengkap dan yang dibutuhkan, memanfaatkan sumber bacaan bisa seperti koran, artikel-artikel maupun berita yang ditanyangkan secara langsung, sehingga hal itu akan menimbulkan minat baca yang baik sampai menjadi kebiasaan dalam membaca. Menurut Burs dan Lowe mengemukakan tentang indikator-indikator adanya minat membaca pada seseoranya yaitu: ${ }^{44}$

a) Kebutuhan terhadap bacaan.

b) Tindakan untuk mencari bacaan.

c) Rasa senang terhadap bacaan.

d) Keinginan selalu membaca.

e) Tindak lanjut (menindaklanjuti dari apa yang dibaca).

Adanya minat membaca dalam diri seseorang karena membaca merupakan merupakan kebutuhan dalam kehidupan sehari-hari baik dalam menyelsaikan sebuah tugas, tindakan mencari bacaan adalah siswa lebih aktif dalam mencari sumber-sumber bacaan yang dibutuhkan, ketika membaca minat adalah munculnya rasa senang pada bacaan, dalam diri seseorang harus ditanamkan pentingnya keinginan selalu membaca guna wawasan bagi siswa, siswa yang memiliki minat membaca akan selalu ada tindakan dalam menindaklanjuti apa yang dibaca artinya saat siswa mendapatkan ilmu atau informasi yang baru siswa dapat melakukan tindak lanjut yaitu melakukannya dalam kehidupannya, tidak hanya sekadar tahu tetapi adanya keinginan untuk bertindak.

\section{Beban Tugas Dosen Meningkatkan Perasaan Senang Membaca}

Tabel 1. Indikator Perasaan Senang

\begin{tabular}{|l|l|l|l|l|l|}
\hline No & Pertanyaan & Setuju & Kadang- & Jarang & Tidak \\
\hline
\end{tabular}

43 Encang Saepudin, “Tingkat Budaya Membaca Masyarakat (Studi Kasus Pada Masyarakat Di Kabupaten Bandung)," Jurnal Kajian Informasi \& Perpustakaan 3, no. 2 (2015): 87, https://doi.org/10.24198/jkip.v3i2.10003.

${ }^{44}$ Dwi Sunar Prasetyono, Rahasia Mengajarkan Gemar Membaca pada Anak Sejak Dini (Jogyakarta: Think, 2018), 59. 


\begin{tabular}{|l|l|c|c|c|c|c|c|c|c|}
\hline \multirow{2}{*}{} & & \multicolumn{2}{|c|}{ kadang } & \multicolumn{2}{|c|}{ Setuju } \\
\cline { 3 - 9 } & & $\mathrm{n}$ & $\%$ & $\mathrm{n}$ & $\%$ & $\mathrm{n}$ & $\%$ & $\mathrm{n}$ & $\%$ \\
\hline 1 & $\begin{array}{l}\text { Saya tidak dipaksa pada saat } \\
\text { mengerjakan tugas makalah } \\
\text { yang diberikan oleh dosen. }\end{array}$ & 38 & 36,19 & 45 & 42,85 & 22 & 20,85 & 0 & 0 \\
\hline 2 & $\begin{array}{l}\text { Dalam keadaan sakit atau } \\
\text { apapun saya akan tetap } \\
\text { menyelesaikan tugas-tugas } \\
\text { seperti laporan bacaan atau } \\
\text { interaksi bacaan yang } \\
\text { diberikan. }\end{array}$ & 30 & 28,57 & 46 & 43,80 & 20 & 19,04 & 9 & 8,57 \\
\hline 3 & $\begin{array}{l}\text { Saya menyelesaikan tugas- } \\
\text { tugas saya dengan cara } \\
\text { belajar sendiri }\end{array}$ & 43 & 40,95 & 46 & 43,80 & 16 & 15,23 & 0 & 0 \\
\hline 4 & $\begin{array}{l}\text { Saya menyediakan waktu } \\
\text { membaca buku yang } \\
\text { diwajibkan dosen setiap hari }\end{array}$ & 30 & 28,57 & 38 & 36,19 & 22 & 20,95 & 15 & 14,28 \\
\hline 5 & $\begin{array}{l}\text { Saya senang ketika tugas- } \\
\text { tugas bacaan yang diberikan } \\
\text { sesuai keinginan saya }\end{array}$ & 43 & 40,95 & 46 & 43,80 & 16 & 15,23 & 0 & 0 \\
\hline
\end{tabular}

Berdasarkan tabel 1, maka dapat dijelaskan bahwa indikator senang pada minat baca dari beberapa pernyataan pada angket adalah sebagai berikut:

Pada tabel 1 pada pertanyaan nomor 1 dari 105 responden diperoleh jawaban yang menjawab setuju 38 (36,19\%) pada saat mengerjakan tugas makalah tidak dipaksa. Ada 45 (42,85\%) responden menjawab kadang-kadang. Ada 22 (20,85\%) responden menjawab jarang dan tidak ada yang menjawab tidak. Menurut salah satu narasumber jawaban kadang-kadang dan jarang karena contohnya seperti pada saat membuat tugas makalah, dan akan dikumpul dalam waktu dekat. Narasumber mengatakan kadang jika melihat teman kerjakan baru tergerak untuk mengerjakan, jika teman santai tugaspun santai. Hal ini membuat banyak responden yang menjawab kadang-kadang dan jarang. Perlu pembiasaan literasi, baik dari membaca maupun 
menulis dilakukan sejak awal dan rutin. ${ }^{45}$ Pengubahan buku cetak menjadi buku elektronik juga dapat menjadi solusi untuk meningkatkan akses membaca. ${ }^{46}$

Pada pertanyaan nomor 2, diperoleh jawaban responden bahwa ada 30 (28,57\%) mahasiswa yang menjawab setuju dalam keadaan apapun bahkan sekalipun sakit akan tetap menyelesaikan tugas-tugas, ada 46 (43,80\%) mahasiswa yang memberikan jawaban kadang-kadang menyelesaikan tugas dalam keadaan apapun bahkan saat sakit akan tetap menyelesaikan tugas, ada 20 (19,04\%) mahasiswa yang memberikan jawaban jarang menyelesaikan tugas dalam keadaan apapun, dan ada 9 (8,57\%) mahasiswa yang menjawab tidak setuju menyelesaikan tugas dalam keadaan sakit. Emosi memiliki hubungan negatif dan positif yang signifikan dengan beban kognitif dan pemahaman kalimat. ${ }^{47}$

Pada pertanyaan nomor 3, diperoleh keterangan dari 105 responden bahwa, ada $30(28,57)$ mahasiswa yang menjawab setuju mengerjakan tugas dengan cara belajar sendiri, ada 38 (36,19\%) mahasiswa yang menjawab kadang-kadang mengerjakan tugas dengan cara sendiri, ada 22 (20,95\%) mahasiswa yang menjawab jarang, dan ada 15 $(14,28 \%)$ mahasiswa yang menjawab tidak setuju mengerjakan tugas dengan cara belajar sendiri. Dari pernyataan beberapa narasumber mengerjakan tugas bersamasama dengan teman kamar maupun teman dekat, ada juga yang mengerjakan tugas karena melihat teman bukan karena keinginan sendiri.

Pada pertanyaan nomor 4, diperoleh keterangan dari 105 responden bahwa, ada 43 (40,95\%) mahasiswa yang memberikan jawaban setuju menyediakan waktu untuk membaca buku yang diwajibkan oleh dosen, ada 46 (43,8\%) mahasiswa yang memberikan jawaban kadang-kadang menyediakan waktu untuk membaca buku yang diwajibkan dosen dan ada 16 (20,95\%) mahasiswa yang memberikan jawaban jarang. Sebagian besar mahasiswa dengan senang membaca buku yang diwajibkan dosen setiap hari dan responden yang menjawab jarang karena buku yang diwajibkan oleh dosen dibaca setiap hari, bisa dibaca hanya dalam beberapa Minggu dan tidak setiap hari.

Pada pertanyaan nomor 5, diperoleh keterangan dari 105 responden bahwa, ada $43(40,95 \%)$ mahasiswa yang menjawab setuju senang ketika diberikan tugas bacaan sesuai keinginan, ada 46 (43,80\%) mahasiswa yang menjawab kadang-kadang senang

\footnotetext{
45 Esti Swatika Sari and Setyawan Pujiono, "Budaya Literasi Di Kalangan Mahasiswa FBS UNY," LITERA 16, no. 1 (June 5, 2017): 105-113.

46 Elga Andina, "Strategi Dosen Dalam Pengondisian Perilaku Membaca Mahasiswa Di Era Digital: Studi Kasus Di Kalimantan Barat Dan Sulawesi Selatan," Aspirasi: Jurnal Masalah-masalah Sosial 8, no. 2 (2017): 195-206.

47 Nazanin Azamnouri, Reza Pishghadam, and Elham Naji Meidani, "The Role of Emotioncy in Cognitive Load and Sentence Comprehension of Language Learners," Issues in Language Teaching 9, no. 1 (June 1, 2020): 29-55.
} 
diberikan tugas bacaan sesuai keinginan, ada 16 (15, 23\%) mahasiswa yang menjawab jarang senang diberikan tugas sesuai keinginan. Menurut salah satu narasumber yang menjawab jarang, jika diberikan tugas bacaan yang sesuai keinginan akan menjadi suatu kebiasaan yang hanya menyukai bacaan itu saja dan tidak membaca buku lain-lainnya. Contohnya membaca buku dan taurat ini merupakan buku wajib yang harus dibaca, tetapi jika hanya membaca sesuai keinginan, membaca buku lainnya kurang minat. Hal ini juga dijelaskan dalam sebuah buku yang mengatakan bahwa kesalahan buka pada buku-buku kuliah tetapi semuanya bersumber dari perasaan senang terhadap suatu bacaan, karena keinginan itu muncul dari rasa cinta terhadap suatu bacaan. ${ }^{48}$

Dari kelima pernyataan di atas dapat disimpulkan berdasarkan hasil penelitian, diperoleh hasil perhitungan rating skala untuk indikator senang yakni sebesar 75, 67\%. Hal ini menunjukkan bahwa persepsi mahasiswa menyatakan setuju bahwa beban tugas membaca dapat memengaruhi minat rasa senang mahasiswa untuk membaca buku.

Pertama ketika mahasiswa mengerjakan tugas dengan senang tanpa dipaksa, menunjukkan lebih banyak menjawab kadang-kadang hal ini menunjukkan bahwa indikator senang terlihat. Dan yang menjawab jarang dan tidak setuju merupakan mahasiswa yang sering menghabiskan waktu mengerjakan tugas karena melihat temantemannya dan harus tunggu waktu mendesak baru mau mengerjakan tugas-tugas. Kedua, mahasiswa senang pada saat menyelesaikan tugas dengan cara dan waktu mereka sendiri dalam kondisi apapun tetap mengerjakannya karena tanggung jawab. Kesimpulannya adalah responden yang menjawab kadang-kadang dapat dikatakan senang dalam mengerjakan tugas-tugas yang diberikan oleh dosen tanpa dipaksa mengerjakan. Salah satu faktor yang memengaruhi minat membaca adalah pengajar. ${ }^{49}$

Beban Tugas Dosen Terhadap Ketertarikan Membaca

Tabel 2. Indikator Ketertarikan Membaca

\begin{tabular}{|c|c|c|c|c|c|c|c|c|c|}
\hline \multirow[t]{2}{*}{ No } & \multirow[t]{2}{*}{ Pertanyaan } & \multicolumn{2}{|c|}{ Setuju } & \multicolumn{2}{|c|}{$\begin{array}{l}\text { Kadang- } \\
\text { kadang }\end{array}$} & \multicolumn{2}{|c|}{ Jarang } & \multicolumn{2}{|c|}{$\begin{array}{l}\text { Tidak } \\
\text { Setuju }\end{array}$} \\
\hline & & $\mathrm{n}$ & $\%$ & $\mathrm{n}$ & $\%$ & $\mathrm{n}$ & $\%$ & $\mathrm{n}$ & $\%$ \\
\hline 1 & Saya membaca buku 2-3 & 30 & 28,57 & 38 & 36,19 & 24 & 22,85 & 13 & 12,38 \\
\hline
\end{tabular}

48 Nasrul Yung, Jangan Berhenti Mencoba (Jakarta: Elex Media Komputindo, 2017).

${ }^{49}$ Marimbun, "Minat Membaca Dan Implementasinya Dalam Bimbingan Dan Konseling," ENLIGHTEN (Jurnal Bimbingan dan Konseling Islam) 2, no. 2 (December 19, 2019): 74-84. 


\begin{tabular}{|l|l|c|c|c|c|c|c|c|c|}
\hline & jam setiap hari. & & & & & & & & \\
\hline 2 & $\begin{array}{l}\text { Saya menyelesaikan tugas } \\
\text { makalah karena keinginan } \\
\text { untuk mendapatkan nilai }\end{array}$ & 35 & 33,33 & 43 & 4095 & 19 & 18,09 & 8 & 7,61 \\
\hline 3 & $\begin{array}{l}\text { Saya memiliki motivasi } \\
\text { menyelesaikan tugas untuk } \\
\text { mendapatkan nilai yang } \\
\text { baik. }\end{array}$ & 38 & 36,19 & 45 & 42,85 & 22 & 20,95 & 0 & 0 \\
\hline 4 & $\begin{array}{l}\text { Jika ada waktu luang saya } \\
\text { selalu membaca dan } \\
\text { mempelajari materi-materi } \\
\text { pelajaran. }\end{array}$ & 35 & 33,33 & 38 & 36,19 & 20 & 19,09 & 12 & 11,42 \\
\hline 5 & $\begin{array}{l}\text { Jika saya gagal dalam 1 } \\
\text { mata kuliah, saya akan } \\
\text { tetap semangat belajar. }\end{array}$ & 40 & 38,09 & 40 & 38,09 & 18 & 17,14 & 7 & 6,66 \\
\hline
\end{tabular}

Berdasarkan tabel 2, maka dapat dijelaskan bahwa indikator tertarik pada minat baca dari beberapa pernyataan pada angket adalah sebagai berikut:

Pada pertanyaan nomor 1, diperoleh keterangan dari 105 responden bahwa, ada $30(28,57 \%)$ mahasiswa yang menjawab setuju membaca 2-3 jam setiap hari, ada 38 $(36,19 \%)$ mahasiswa yang menjawab kadang-kadang membaca 2-3 jam setiap hari, ada $24(22,85 \%)$ mahasiswa yang menjawab jarang, dan ada 13 (12,38\%) mahasiswa yang menjawab tidak setuju membaca 2-3 jam setiap hari. Menurut beberapa narasumber yang menjawab jarang dan tidak pernah karena jika hanya ada waktu luang baru membaca dan jika ada buku yang menarik baru membaca dan bisa lebih dari 3-4 jam. Karena itu, media pembelajaran komik berpengaruh positif terhadap minat baca dan dapat meningkatkan hasil belajar siswa. 50

Pada pertanyaan nomor 2, diperoleh keterangan dari 105 responden bahwa, ada $35(33,33 \%)$ mahasiswa yang menjawab setuju menyelesaikan tugas makalah karena ingin mendapatkan nilai, ada 43 (40,95\%) mahasiswa yang menjawab kadang-kadang menyelesaikan tugas makalah karena nilai, ada 19 (18,09\%) mahasiswa yang menjawab jarang, dan ada $8(7,61 \%)$ mahasiswa yang menjawab tidak setuju menyelesaikan tugas makalah karena ingin mendapatkan nilai, alasannya karena responden banyak yang mengerjakan makalah karena tanggung jawab dan tidak hanya untuk sekadar mendapat

50 Ira Wulandari Suparman, Marlina Eliyanti, and Eli Hermawati, "Pengaruh Penyajian Materi Dalam Bnetuk Media Komik Terhadap Minat Baca Dan Hasil Belajar,” Pedagogi: Jurnal Penelitian Pendidikan 7, no. 1 (May 30, 2020): 57-64. 
nilai tetapi juga tanggung jawab. Dalam penelitian menurut Rosmiasih juga mengatakan bahwa tujuan pemberian tugas tidak hanya untuk mendapatkan nilai tetapi dapat menumbuhkembangkan pengetahuan kinerja otak dan membiasakan diri membaca dengan tujuan menemukan informasi. 51

Pada pertanyaan nomor 3, diperoleh keterangan dari 105 responden bahwa, ada $32(30,47 \%)$ mahasiswa yang menjawab setuju mendapatkan nilai yang baik adalah motivasi untuk menyelesaikan tugas, ada 55 (52,38\%) mahasiswa yang menjawab kadang-kadang mendapatkan nilai yang baik adalah motivasi, ada 12 (11,42\%) mahasiswa yang menjawab jarang, dan ada $6(5,71 \%)$ mahasiswa yang menjawab tidak pernah mendapatkan nilai yang baik adalah motivasi. Responden yang menjawab jarang dan tidak pernah merupakan alasannya karena sekolah di STF Jaffray tidak hanya motivasi mendapatkan nilai baik tetapi juga merupakan tanggung jawab yang harus diselesaikan.

Pada pertanyaan nomor 4, diperoleh keterangan dari 105 responden bahwa, ada 35 (33,33\%) mahasiswa yang menjawab setuju membaca dan mempelajari materimateri pelajaran, ada 38 (36,19\%) mahasiswa yang banyak menjawab kadang-kadang membaca dan mempelajari materi-materi pelajaran, ada 20 (19,04\%) mahasiswa yang menjawab jarang, dan ada 12 (11,42\%) mahasiswa yang menjawab tidak setuju pada saat ada waktu luang membaca dan mempelajari materi pelajaran. Menurut narasumber tergantung pada kegiatan atau kesibukkan yang sedang dikerjakan, narasumber juga biasa membaca materi pelajaran sebelum 1 hari pelajaran dimulai.

Pada pertanyaan nomor 5, diperoleh keterangan dari 105 responden bahwa, ada $40(38,09 \%)$ mahasiswa yang menjawab setuju jika gagal dalam 1 mata kuliah tetap semangat belajar, ada 40 (39,09\%) mahasiswa yang menjawab kadang-kadang jika gagal 1 mata kuliah tetap semangat belajar, ada 18 (17,14\%) mahasiswa yang menjawab jarang, dan ada 7 (6,66\%) mahasiswa yang menjawab tidak setuju jika gagal pada 1 mata kuliah tetap semangat belajar. Karena berdasarkan jawaban responden, narasumber menjawab dengan percaya diri tidak pernah akan gagal pada 1 mata kuliah karena semangat dan rajinnya kerjakan tugas-tugas. Penelitian menurut Ade Irma dan Tri Esti juga menyatakan bahwa orang yang berprestasi pernah gagal tetapi memiliki motivasi untuk terus semangat walaupun pernah mengalami kegagalan. Di sini penulis melihat bahwa kegagalan sekalipun dikalahkan dengan motivasi untuk berprestasi.

51 Rosmiasih, "Metode Penugasan Membuat Ringkasan Sebagai Alternatif Untuk Meningkatkan Hasil Belajar Hewan (Animalia) Siswa Kelas X SMA Negeri 1 Pangkalpinang," Jurnal Profesi Keguruan 5, no. 1 (May 12, 2019): 50-54. 
Dari kelima pernyataan di atas dapat disimpulkan bahwa, berdasarkan hasil penelitian, diperoleh perhitungan rating skala untuk indikator keteratarikan yakni 74,62\%. Hal ini menunjukkan bahwa persepsi mahasiswa mengenai beban tugas membaca memengaruhi ketertarikan mahasiswa dalam membaca.

Pertama, mahasiswa dikatakan tertarik dalam membaca sebuah buku ketika mahasiswa menyediakan waktu membaca 2-3 jam setiap hari dengan presentase 74, $62 \%$ menunjukkan adanya ketertarikan pada bacaan. Kedua, dalam menyelesaikan tugas-tugas yang mempengaruhi minat membaca mahasiswa karena motivasi adalah mendapatkan nilai yang baik. Namun, ada juga yang mengatkan bahwa menyelesaikan tugas tidak hanya untuk mendapat nilai tetapi karena tanggung jawab yang besar terhadap sekolah. Menurut Romsmiasih menyatakan bahwa menyelesaikan tugas tidak hanya tujuan mendapatkan nilai tetapi sebagai kewajiban mahasiswa. ${ }^{52}$ Sebagian besar dari indikator tertarik, responden mampu memiliki motivasi pada saat mengerjakan tugas-tugas yang diberikan.

\section{Beban Tugas Dosen Terhadap Perhatian Membaca}

Tabel 3. Indikator Perhatian

\begin{tabular}{|c|c|c|c|c|c|c|c|c|c|}
\hline \multirow[t]{2}{*}{ No } & \multirow[t]{2}{*}{ Pertanyaan } & \multicolumn{2}{|c|}{ Setuju } & \multicolumn{2}{|c|}{$\begin{array}{l}\text { Kadang- } \\
\text { kadang }\end{array}$} & \multicolumn{2}{|c|}{ Jarang } & \multicolumn{2}{|c|}{$\begin{array}{l}\text { Tidak } \\
\text { Setuju }\end{array}$} \\
\hline & & $\mathrm{n}$ & $\%$ & $\mathrm{n}$ & $\%$ & $\mathrm{n}$ & $\%$ & $\mathrm{n}$ & $\%$ \\
\hline 1 & $\begin{array}{l}\text { Saya membaca buku } \\
\text { 15-20 menit sebelum } \\
\text { ujian atau kuis-kuis } \\
\text { dimulai. }\end{array}$ & 30 & 28,57 & 38 & 36,19 & 24 & 22,85 & 13 & 12,38 \\
\hline 2 & $\begin{array}{l}\text { Saya membaca sebuah } \\
\text { kalimat yang menarik } \\
\text { pada saat mengerjakan } \\
\text { tugas interaksi bacaan, } \\
\text { saya akan membacanya } \\
\text { berulang-ulang. }\end{array}$ & 30 & 28,57 & 52 & 49,52 & 23 & 21,90 & 0 & 0 \\
\hline 3 & $\begin{array}{l}\text { Saya mampu } \\
\text { menyimpulkan makna } \\
\text { dari setiap akhir } \\
\text { bacaan. }\end{array}$ & 30 & 28,57 & 48 & 45,71 & 27 & 25,71 & 0 & 0 \\
\hline
\end{tabular}

52 Ibid. 


\begin{tabular}{|l|l|c|c|c|c|c|c|c|c|}
\hline 4 & $\begin{array}{l}\text { Saya mampu } \\
\text { mengaitkan bacaan } \\
\text { yang sedang dibaca } \\
\text { dengan informasi yang } \\
\text { sudah ada. }\end{array}$ & 42 & 40 & 46 & 43,80 & 17 & 16,19 & 0 & 0 \\
\hline 5 & $\begin{array}{l}\text { Pada saat kelas dimulai } \\
\text { saya mampu } \\
\text { berkonsentrasi selama } \\
\text { kuliah berlangsung }\end{array}$ & 30 & 28,57 & 44 & 41,90 & 23 & 21,90 & 8 & 7,61 \\
\hline
\end{tabular}

Berdasarkan tabel 3, maka dapat dijelaskan bahwa indikator perhatian pada minat baca dari beberapa pernyataan pada angket adalah sebagai berikut:

Pada pertanyaan nomor 1 , diperoleh keterangan dari 105 responden bahwa, ada $30(28,57 \%)$ responden yang menjawab setuju membaca 15-20 menit membaca sebelum ujian atau kuis-kuis dimulai, ada 38 (36,19\%) responden yang menjawab kadang-kadang membaca 15-20 menit sebelum ujian atau kuis-kuis dimulai, ada 24 $(22,85 \%)$ responden yang menjawab jarang menyediakan waktu membaca 15-20 sebelum ujian, ada 13 (12,38\%) responden yang menjawab tidak setuju membaca 15-20 menit sebelum ujian dimulai. Berdasarkan narasumber yang jarang dan tidak setuju karena responden biasa membaca sebelum 1-2 jam dimulai karena kelas yang lanjut, contoh dari jam 9-11 dan dilanjutkan jam 11-13 siang. Juga ada yang membaca materi ujian dalam jangka waktu dekat tetap membaca. Berpikir dapat dilatihkan pada mahasiswa. Secara khusus mahasiswa dituntut untuk berpikir kritis dalam mempelajari dan mempraktekkan ilmunya. ${ }^{53}$

Pada pertanyaan nomor 2, diperoleh keterangan dari 105 responden bahwa, ada 30 (28,57\%), mahasiswa yang menjawab setuju menemukan sebuah kalimat yang menarik pada saat mengerjakan interaksi bacaan, saya akan terus mengulang-ulang membacanya, ada 52 (49,52\%) mahasiswa yang menjawab kadang-kadang membaca ulang-ulang kalimat yang menarik, ada 23 (21,90\%) mahasiswa yang menjawab jarang mengulang-ulang kalimat pada saat mengerjakan interaksi bacaan. Mahasiswa yang menjawab jarang ini adalah mahasiswa yang dengan mudah menangkap makna langsung sekali membaca. Karena semakin tinggi minat baca maka akan semakin tinggi

${ }^{53}$ Mulyadi Mulyadi, Adlim Adlim, and Djufri Djufri, "Memberdayakan Kemampuan Berpikir Mahasiswa Melalaui Model Pembelajaran Reading Questioning and Answering (RQA)," BIOTIK: Jurnal Ilmiah Biologi Teknologi dan Kependidikan 2, no. 1 (February 8, 2018): 33-37. 
pula prestasi belajar, begitu juga sebaliknya semakin rendah minat baca semakin rendah pula prestasi belajar. ${ }^{54}$

Pada pertanyaan nomor 3, diperoleh keterangan dari 105 responden bahwa, ada 30 (28,57\%) mahasiswa yang menjawab setuju mampu menyimpulkan makna dari setiap bacaan, ada 48 (45,71\%) mahasiswa yang menjawab kadang-kadang mampu menyimpulkan makna dari setiap bacaan, ada 27 (25,71\%) mahasiswa yang menjawab jarang mampu menyimpulkan makna dari setiap bacaan. Menurut salah satu narasumber yang menjawab jarang, karena pada saat membaca sambil memainkan hpnya sehingga susah menyimak bacaan dengan sungguh-sungguh. Minat baca mahasiswa juga sangat berkaitan dengan kesadaran mahasiswa untuk membaca. ${ }^{55}$

Pada pertanyaan nomor 4, diperoleh keterangan dari 105 responden bahwa, ada 42 (40\%) mahasiswa yang menjawab setuju mampu berkonsentrasi saat kuliah berlangsung, 46 (43,80\%) mahasiswa yang menjawab kadang-kadang mampu berkonsentrasi pada saat kuliah berlangsung, ada 17 (16,19\%) mahasiswa yang menjawab jarang mampu berkonsentrasi pada saat kuliah berlangsung. Menurut beberapa narasumber yang menjawab jarang, karena bergantung pada teman sebangkunya. Jika temannya serius, maka ia juga akan serius.

Pada pertanyaan nomor 5, diperoleh keterangan dari 105 responden bahwa, ada $30(28,57 \%)$ mahasiswa yang menjawab setuju mampu mengaitkan bacaan yang dibaca dengan informasi yang sudah ada, ada 44 (41,90\%) mahasiswa yang menjawab kadangkadang mampu mengaitkan bacaan yang sedan dibaca dengan informasi yang sudah ada, ada $23(21,90 \%)$ mahasiswa yang menjawab jarang, ada $8(7,61 \%)$ mahasiswa yang menjawab tidak setuju, mampu mengaitkan bacaan yang sedang dibaca dengan informasi yang sudah ada, karena mahasiswa lebih banyak membaca dengan fokus menyelesaikan tugas saja tetapi tidak melihat makna dari setiap bacaan.

Dari kelima pernyataan dapat dijelaskan bahwa berdasarkan hasil penelitian, diperoleh hasil perhitungan rating skala untuk indikator perhatian yakni $75,85 \%$. Hal ini menunjukkan bahwa persepsi mahasiswa mengenai beban tugas membaca memengaruhi perhatian mahasiswa dalam minat baca.

Pertama, beban tugas yang diberikan oleh dosen mampu membuat mahasiswa memiliki minat baca yang membutuhkan perhatian seperti mampu menyimpulkan bacaan, membaca buku sebelum ujian dimulai, membaca diulang-ulang karena ada

${ }^{54}$ Arif Widodo et al., "Prestasi Belajar Mahasiswa PGSD PAda Mata KUliah Pengantar Pendidikan Ditinjau Dari Segi Minat Baca," Jurnal Bidang Pendidikan Dasar (JBPD)JBPD 4, no. 1 (January 27, 2020): $38-46$.

${ }^{55}$ Febrina Dafit, Dea Mustika, and Ningrum Melihayatri, "Pengaruh Program Pojok Literasi Terhadap Minat Baca Mahasiswa," Jurnal Basicedu 4, no. 1 (January 24, 2020): 117-130. 
perhatian yang penuh. Kedua, ada yang mampu berkonsentrasi dan mampu mengaitkan pada suatu bacaan. Ada juga yang menjawab jarang dan tidak setuju karena bergantung dengan teman yang duduk sama-sama hal ini menunjukkan adanya faktor dari teman sebaya yang mengakibatkan konsentrasi yang kurang baik.

\section{Beban Tugas Dosen Terhadap Keterlibatan}

Tabel 4. Indikator Keterlibatan

\begin{tabular}{|c|c|c|c|c|c|c|c|c|c|}
\hline \multirow[t]{2}{*}{ No } & \multirow[t]{2}{*}{ Pertanyaan } & \multicolumn{2}{|c|}{ Setuju } & \multicolumn{2}{|c|}{$\begin{array}{l}\text { Kadang- } \\
\text { kadang }\end{array}$} & \multicolumn{2}{|c|}{ Jarang } & \multicolumn{2}{|c|}{$\begin{array}{l}\text { Tidak } \\
\text { Setuju }\end{array}$} \\
\hline & & $\mathrm{n}$ & $\%$ & $\mathrm{n}$ & $\%$ & $\mathrm{n}$ & $\%$ & $\mathrm{n}$ & $\%$ \\
\hline 1 & $\begin{array}{l}\text { Saya pernah terlibat } \\
\text { memainkan drama dalam } \\
\text { kelas pada } 1 \text { mata kuliah } \\
\text { berupa tugas kelompok. }\end{array}$ & 53 & 50,47 & 33 & 31,42 & 19 & 18,09 & 0 & 0 \\
\hline 2 & $\begin{array}{l}\text { Saya membaca buku yang } \\
\text { diberiikan dosen karena } \\
\text { kemauan untuk } \\
\text { menyelesaikan tugas-tugas. }\end{array}$ & 35 & 33,33 & 45 & 42,85 & 25 & 23,80 & 0 & 0 \\
\hline 3 & $\begin{array}{l}\text { Saya mampu menjelaskan } \\
\text { kembali makna dari tugas- } \\
\text { tugas yang diberikan dosen } \\
\text { kepada teman-teman yang } \\
\text { bertanya. }\end{array}$ & 35 & 33,33 & 37 & 35,23 & 25 & 23,80 & 8 & 7,6 \\
\hline 4 & $\begin{array}{l}\text { Memainkan suatu peran } \\
\text { dalam drama mampu } \\
\text { membuat saya berinteraksi } \\
\text { dengan bacaan dan teman- } \\
\text { temaan. }\end{array}$ & 35 & 33,33 & 42 & 40 & 21 & 20 & 7 & 6,66 \\
\hline 5 & $\begin{array}{l}\text { Salah satu mata kuliah } \\
\text { pernah diberikan tugas } \\
\text { menonton film kemudian } \\
\text { diminta untuk menceritakan } \\
\text { kembali kepada teman- } \\
\text { teman di kelas. }\end{array}$ & 33 & 31,42 & 43 & 40,95 & 21 & 20 & 8 & 7,61 \\
\hline
\end{tabular}


Berdasarkan tabel 4, maka dapat dijelaskan bahwa indikator perhatian pada minat baca dari beberapa pernyataan pada angket adalah sebagai berikut:

Pada pertanyaan nomor 1, diperoleh keterangan dari 105 responden bahwa, ada $53(50,47 \%)$ mahasiswa yang menjawab setuju pernah terlibat memainkan drama, ada 33 (31,42\%) responden menjawab kadang-kadang. Ada 19 (18,09\%) mahasiswa yang menjawab jarang memainkan drama pada 1 kelas. Responden yang menjawab jarang dari beberapa mengungkapkan bahwa karena dirinya sangat pendiam dan tidak suka terlibat dalam suatu bagian di kelas. Ia pernah terlibat tetapi tidak terlalu berinteraksi dengan teman-temannya.

Pada pertanyaan nomor 2, diperoleh keterangan dari 105 responden bahwa, ada 35 (33,33\%) mahasiswa yang menjawab setuju membaca karena kemauan untuk menyelesaikan tugas, ada 45 (42,85\%) mahasiswa yang menjawab kadang-kadang membaca karena menyelesaikan tugas, ada 25 (23,80\%) mahasiswa yang menjawab jarang membaca untuk menyelesaikan tugas. Dengan demikian, terlihat dari jawaban responden jarang karena membaca jika tertarik maka tidak hanya pada saat menyelesaikan tugas tetapi karena kemauan. Rendahnya minat membaca mahasiswa disebabkan oleh kurangnya perhatian, dukungan, faktor pesatnya teknologi, pengelolaan perpustakaan dan pengawasan dari keluarga terhadap kegiatannya. ${ }^{56}$

Pada pertanyaan nomor 3, diperoleh keterangan dari 105 responden bahwa, ada $35(33,33 \%)$ mahasiswa yang menjawab setuju mampu menjelaskan kepada teman jika ada yang bertanya tentang tugas, ada 37 (35,23\%) mahasiswa yang menjawab kadangkadang mampu menjelaskan kepada teman jika ada yang bertanya, ada 25 (23,80\%) mahasiswa yang menjawab jarang, ada $8(7,61)$ mahasiswa yang menjawab tidak setuju mampu menjelaskan tugas kepada temannya yang bertanya. Karena yang menjawab jarang dan tidak setuju adalah orang-orang yang temannya tidak bertanya.

Pada pertanyaan nomor 4, diperoleh keterangan dari 105 responden bahwa, ada $35(33,33 \%)$ mahasiswa yang menjawab setuju memainkan peran membuat saling berinteraksi dan melibatkan orang lain, ada 42 (40\%) mahasiswa yang menjawab kadang-kadang memainkan peran mampu berinteraksi dengan bacaan dan temanteman, ada 21 (20\%) mahasiswa yang menjawab jarang, ada 7 (6,66\%) mahasiswa yang memberikan jawaban tidak setuju memainkan suatu peran mampu membuat saling berinteraksi dengan teman-teman. Karena yang menjawab jarang dan tidak pernah karena memainkan drama saja tanpa memperdulikan orang yang disekitarnya. Ini menjadi penyebab sebagian responden yang menjawab jarang atau tidak pernah.

\footnotetext{
56 Shindriani Putri, "Pemanfaatan Internet Untuk Meningkatkan Minat Baca Mahasiswa PLS IKIP Siliwangi," Comm-Edu (Community Education Journal) 3, no. 2 (May 8, 2020): 91-97.
} 
Pada pertanyaan nomor 5, diperoleh keterangan dari 105 responden bahwa, ada 33 (31,42\%) mahaasiswa yang menjawab setuju pernah menonton film dan menceritakannya di kelas, ada 43 (40,95\%) mahasiswa yang menjawab kadang-kadang pernah menonton film kemudian menceritakannya kepada teman-teman, ada 21 (20\%) mahasiswa yang menjawab jarang, ada 8 (7,61\%) mahasiswa yang menjawab tidak setuju pernah menonton film di kelas kemudian menceritakannya kepada teman-teman di kelas, karena ada yang hanya menonton film tetapi tidak mendapat kesempatan menceritakkan kembali di kelas terbatas waktu, juga ada yang menonton film tetapi kesimpulannya dituangkan dalam bentuk tulisan. Film sebagai media pembelajaran yang menyenangkan, mahasiswa diharapkan dapat lebih mudah menuangkan ideide kritis untuk menulis esai argumentasi. ${ }^{57}$ Film dianggap sebagai komunikator yang efektif, membangkitkan emosi dan merangsang perasaan siswa. ${ }^{58}$

Dari kelima pernyataan di atas dapat disimpulkan bahwa, berdasarkan hasil penelitian, diperoleh hasil perhitungan rating skala untuk indikator keterlibatan yakni sebesar 76,51\%. Hal ini menunjukkan bahwa persepsi mahasiswa mengenai beban tugas bacaan memengaruhi perhatian mahasiswa dalam minat baca.

Pertama, tugas yang diberikan dosen mampu membuat mahasiswa saling berinteraksi dan terlibat langsung. Seperti tugas kelompok diminta untuk bermian peran di depan kelas oleh dosen, hal ini akan membantu mahasiswa terlibat secara langsung dalam sebuah tugas. Sehingga beban tugas yang diberikan mampu meningkatkan minat baca mahasiswa baik dalam memainkan sebuah drama atau berinteraksi. Kedua, dilihat bahwa presentase 76,51\% menunjukkan presentase antara setuju dan kadang-kadang namun jawabannya lebih besar kadang-kadang hal ini dilihat dari pernyataan responden yang mampu menjelaskan dengan baik isi atau inti dari tugas-tugas yang diberikan oleh dosen kepada mahasiswa juga mahasiswa dapat terlibat secara aktif dalam kelas dan ini menjadi harapan setiap dosen dalam semua materi yang dijelaskan. Oleh sebab itu dikatakan indikator keterlibatan mampu mempengaruhi peningkatan minat baca mahasiswa STF Jaffray Makassar yang.

Pembahasan penelitian yang telah dilakukan terhadap 105 orang mahasiswa di STF Jaffray Makassar mengenai pengaruh beban tugas membaca terhadap peningkatan

\footnotetext{
${ }^{57}$ Fatimah Mulya Sari, "Persepsi Mahasiswa Terhadap Implementasi Film Dalam Pembelajaran Menulis Esai Argumentasi," in Seminar Nasional Bahasa Dan Sastra, 2017, 1-6.

58 Pamela Ayesma, Kurniawati, and Nurzengky Ibrahim, "Film Sejarah Sebagai Media Dalam Mengembangkan Literasi Di Era Digital," in Prosiding Seminar Nasional Pascasarjana, vol. 1, 2020, 311322.
} 
minat baca mahasiswa. Dari tabel yang dikemukakan di dalam analisis data mengenai variabel beban tugas dan peningkatan minat baca mahasiswa, dapat dirangkumkan sebagai berikut:

Pertama, beban tugas membaca merupakan bentuk-bentuk tugas yang diberikan oleh dosen kepada mahasiswa untuk meningkatkan minat baca mahasiswa. Sesuai dengan teori yang terdapat dalam bab dua yang menjelaskan bagaimana beban tugas mempengaruhi minat baca mahasiswa yang mampu memiliki perasaan senang terhadap bacaan yang diberikan dalam bentuk tugas dan mahasiswa mengerjakan tugas-tugas dengan adanya inisiatif sendiri. Kedua, mahasiswa mampu membaca 2-3 jam membuktikan bahwa adanya ketertarikan dalam membaca dan adanya motivasi mahasiswa untuk mendapatkan nilai yang baik menunjukkan bahwa adanya ketertarikan. Ketiga, mampu memiliki perhatian dengan berkonsentrasi pada saat pelajaran diberikan oleh dosen juga mampu menjelaskan kembali apa yang menjadi bagian dari tugas yang diberikan. Keempat, mampu terlibat dalam suatu kegiatan yang bersifat positif. Baik itu berupa tugas kelompok maupun tugas pribadi yang akan membuat mahasiswa aktif dalam kelas. Di samping itu juga mampu berinteraksi dan menceritakan apa yang dibaca kepada orang lain.

Adanya sebuah peningkatan pada akademik mahasiswa ditunjukkan melalui prestasi maupun nilai-nilai yang diperoleh pada saat kuliah. Demikian halnya dengan mahasiswa STF Jaffray yang dituntut untuk memiliki nilai-nilai yang baik. Beban tugas membaca adalah tugas-tugas yang diberikan oleh dosen kepada mahasiswa guna membuat mahasiswa belajar dan membaca. Beban tugas tersebut antara lain laporan bacaan, makalah, tugas-tugas kelompok, interaksi bacaan, UTS dan UAS. Tugas-tugas yang diberikan tersebut akan membuat mahasiswa STF Jafrray membaca karena mahasiswa tanpa membaca tidak dapat menyelesaikan tugas dan tanggung jawabnya kepada akademik.

\section{Kesimpulan}

Berdasarkan pembahasan dan hasil penelitian ini, maka penulis dapat menarik kesimpulan sebagai berikut: Pertama, beban tugas adalah tugas-tugas yang diberikan dosen kepada mahasiswa STF Jaffray Makassar sebagai tanggung jawab untuk memenuhi persyaratan kelulusan tiap-tiap mata kuliah dan mahasiswa pasti memiliki target untuk mandapatkan hasil yang maksimal dalam penyelesaian tugas-tugas, sehingga dengan adanya tugas-tugas yang diberikan membuat mahasiswa memiliki kewajiban bahwa menyelesaikan tugas-tugas harus membaca buku. 
Kedua, beban tugas membaca yang diberikan kepada mahasiswa tujuannya untuk meningkatkan minat baca mahasiswa sehingga, mahasiswa STF Jaffray Makassar menggunakan waktu dengan baik selama proses perkuliahan berlangsung, sehingga mahasiswa menyediakan waktu membaca setiap hari. Dan memiliki motivasi dalam menyelesaikan tugas-tugas yang diberikan dosen yaitu untuk mendapat nilai yang baik.

Ketiga, beban tugas yang diberikan mampu membuat mahasiswa ikut terlibat baik dalam merespons suatu bacaan maupun membagikan apa yang didapatkan kepada orang lain dengan kata lain mampu menjabarkan apa yang dibaca kepada orang lain terlebih diri sendiri. Keempat, beban tugas dapat meningkatkan minat baca mahasiswa STF Jaffray Makassar karena ketika mahasiswa menyelesaikan tugas-tugas pasti membaca buku atau membaca sumber-sumber lainnya untuk menjawab tugas-tugas yang diberikan.

\section{Referensi}

Aini, Ibunda. Membaca \& Menulis Seasyik Bermain. Bandung: Mizan Media Utama, 2006. Alfian, Magdalia. "Pendidikan Sejarah Dan Permasalahn Yang Dihadapi." Khazanah Pendidikan 3, no. 2 (February 1, 2011): 1-8.

Andina, Elga. "Strategi Dosen Dalam Pengondisian Perilaku Membaca Mahasiswa Di Era Digital: Studi Kasus Di Kalimantan Barat Dan Sulawesi Selatan." Aspirasi: Jurnal Masalah-masalah Sosial 8, no. 2 (2017): 195-206.

Ayesma, Pamela, Kurniawati, and Nurzengky Ibrahim. "Film Sejarah Sebagai Media Dalam Mengembangkan Literasi Di Era Digital.” In Prosiding Seminar Nasional Pascasarjana, 1:311-322, 2020.

Azamnouri, Nazanin, Reza Pishghadam, and Elham Naji Meidani. "The Role of Emotioncy in Cognitive Load and Sentence Comprehension of Language Learners." Issues in Language Teaching 9, no. 1 (June 1, 2020): 29-55.

Bangsawan, Irwan P. Ratu. Minat Baca Siswa. Bayuasin: Dinas Pendidikan, Pemuda, Olahraga, dan Pariwisata Kabupaten Banyuasin, 2018.

Dafit, Febrina, Dea Mustika, and Ningrum Melihayatri. "Pengaruh Program Pojok Literasi Terhadap Minat Baca Mahasiswa." Jurnal Basicedu 4, no. 1 (January 24, 2020):

117-130.

Darmono. Perpustakaan Sekolah. Jakarta: Grasindo, 2007.

Hasibuan, Sri Wahyuni. "Kebiasaan Membaca Dan Pilihan Bacaan Pada Mahasiswa Pria Dan Wanita Di Universita Pembangunan Panca Budi." JUMANT 10, no. 2 (December 11, 2018): 75-84.

Hidayah, Nurul, Sarwiji Suwandi, and Sri Hastuti. "Penerapan Metode PQRST Untuk Meningkatkan Minat Dan Kemampuan Membaca Pemahaman Siswa." BASASTRA 2, no. 3 (August 1, 2014). Accessed June 4, 2021.

https://jurnal.fkip.uns.ac.id/index.php/bhs_indonesia/article/view/7792. 
Iwan, Hidayat Wahyu. Keterampilan Belajar (Study Skills) Untuk Mahasiswa. Jakarta: Kencana, 2018.

Karno, Perpustakaan Proklamator Bung. Buletin Perpustakaan Bung Karno. Th. IX / Vol. I / 2017: Media Informasi Perpustakaan Bung Karno. Perpustakaan ProklamatorBung Karno, n.d.

Laukapitang, Yunus. Wawancara Oleh Penulis, 25 Maret. Makassar, 2019.

Luthfiyah, Muh Fitrah \&. Metodologi penelitian: penelitian kualitatif, tindakan kelas \& studi kasus. Jawa Barat: CV Jejak (Jejak Publisher), 2018.

Maharani, Ony Dina. "Minat Baca Anak-Anak Di Kampoeng Baca Kabupaten Jember." Jurnal Review Pendidikan Dasar: Jurnal Kajian Pendidikan dan Hasil Penelitian 3,

no. 1 (January 15, 2017): 320-328. Accessed April 30, 2019. https://journal.unesa.ac.id/index.php/PD/article/view/1646.

Marimbun. "Minat Membaca Dan Implementasinya Dalam Bimbingan Dan Konseling." ENLIGHTEN (Jurnal Bimbingan dan Konseling Islam) 2, no. 2 (December 19, 2019): 74-84.

Meliyawati. Pemahaman Dasar Membaca. Yogyakarta: Deepublish, 2016. . Pemahaman Dasar Membaca. Deepublish, 2016.

Mulya Sari, Fatimah. "Persepsi Mahasiswa Terhadap Implementasi Film Dalam Pembelajaran Menulis Esai Argumentasi.” In Seminar Nasional Bahasa Dan Sastra, 1-6, 2017.

Mulyadi, Mulyadi, Adlim Adlim, and Djufri Djufri. "Memberdayakan Kemampuan Berpikir Mahasiswa Melalaui Model Pembelajaran Reading Questioning and Answering (RQA)." BIOTIK: Jurnal Ilmiah Biologi Teknologi dan Kependidikan 2, no. 1 (February 8, 2018): 33-37.

Ni'matullah, Onik Farida. "Pengaruh Minat Dan Kebiasaan Membaca Siswa Terhadap Hasil Belajar Geografi SMA." JPIG (Jurnal Pendidikan dan Ilmu Geografi) 3, no. 1 (2018): 197-205.

Putri, Shindriani. "Pemanfaatan Internet Untuk Meningkatkan Minat Baca Mahasiswa PLS IKIP Siliwangi.” Comm-Edu (Community Education Journal) 3, no. 2 (May 8, 2020): 91-97.

Romafi, Romafi, and Tadkiroatun Musfiroh. "Hubungan Minat Membaca, Fasilitas Orang Tua, Dan Pemberian Tugas Membaca Dengan Kemampuan Membaca Pemahaman Siswa." Ling Tera 2, no. 2 (October 3, 2015): 185-199.

Rosmiasih. "Metode Penugasan Membuat Ringkasan Sebagai Alternatif Untuk Meningkatkan Hasil Belajar Hewan (Animalia) Siswa Kelas X SMA Negeri 1 Pangkalpinang." Jurnal Profesi Keguruan 5, no. 1 (May 12, 2019): 50-54.

Saepudin, Encang. "Tingkat Budaya Membaca Masyarakat (Studi Kasus Pada Masyarakat Di Kabupaten Bandung)." Jurnal Kajian Informasi \& Perpustakaan 3, no. 2 (December 30, 2015): 271-282. Accessed April 30, 2019. http://journal.unpad.ac.id/jkip/article/view/10003.

Sari, Esti Swatika, and Setyawan Pujiono. "Budaya Literasi Di Kalangan Mahasiswa FBS UNY.” LITERA 16, no. 1 (June 5, 2017): 105-113.

Sari, Siti Purnama, Andika Triansyah, and Eka Supriatna. "Minta Membaca Mahasiswa Pendidikan Jasmani Di Perpustakaan Jurusan Ilmu Keolahragaan." Jurnal Pendidikan dan Pembelajaran Khatulistiwa 8, no. 3 (March 21, 2019): 1-11. 
Sello, Hendrik. Wawancara Oleh Penulis, 6 Februari. Makassar, 2019.

Srindahningsih. Jurus Epic Membaca: Cara Menciptakan Hobi Membaca. Sidoarjo: Embrio Plugbise, 2017.

Sugiarti, Uci. "Pentingnya Pembinaan Kegiatan Membaca Sebagai Implikasi Pembelajaran Bahasa Indonesia." Basastra 1, no. 1 (June 27, 2012): 1-11.

Sugiyono. Metode Penelitian Pendidikan Pendekatan Kuantitatif, Kualitatif, Dan R\&D. Bandung: Alfabeta, 2014.

Sun, Peng Kheng. To Be an Innovator. Jakarta: Gramedia Pustaka Utama, 2013.

Sunaiyah, Salma. "Memacu Minat Membaca Bebas (Perpstakaan) Melalui Tugas Menulis." UNIVERSUM: Jurnal KeIslaman dan Kebudayaan 9, no. 1 (January 1, 2015): 117-129.

Suparman, Ira Wulandari, Marlina Eliyanti, and Eli Hermawati. "Pengaruh Penyajian Materi Dalam Bnetuk Media Komik Terhadap Minat Baca Dan Hasil Belajar." Pedagogi: Jurnal Penelitian Pendidikan 7, no. 1 (May 30, 2020): 57-64.

Surangga, I Made Ngurah. "Mendidik Lewat Literasi Untuk Pendidikan Berkualitas." Jurnal Penjaminan Mutu 3, no. 2 (August 31, 2017): 154-163.

Wahyuni, Sri. "Menubuhkembangkan Minat Baca Menuju Masyarakat Literat." Diksi 16, no. 2 (November 4, 2015): 1-11.

Widodo, Arif, Dyah Indraswati, Aisa Rahmatih Nikmah, and Setiani Novitasari. "Prestasi Belajar Mahasiswa PGSD PAda Mata KUliah Pengantar Pendidikan Ditinjau Dari Segi Minat Baca." Jurnal Bidang Pendidikan Dasar (JBPD)JBPD 4, no. 1 (January 27, 2020): 38-46.

Wijaya, Hengki. Metodologi Penelitian Pendidikan Teologi. Makassar: Sekolah TinggiTheologia Jaffray Makassar, 2016.

Yetti, Rivda. "Pengaruh Keterlibatan Orang Tua Terhadpa Minat Membaca Anak Ditinjau Dari Pendekatan Stres Lingkungan." PEDAGOGI / Jurnal Ilmiah Ilmu Pendidikan IX, no. 1 (August 14, 2009): 17-28.

Yudantara, I Ketut Gede. Mengubah Ketidakpastian Menjadi Peluang. Jakarta: Elex Media Komputindo, 2006.

Yung, Nasrul. Jangan Berhenti Mencoba. Jakarta: Elex Media Komputindo, 2017. 